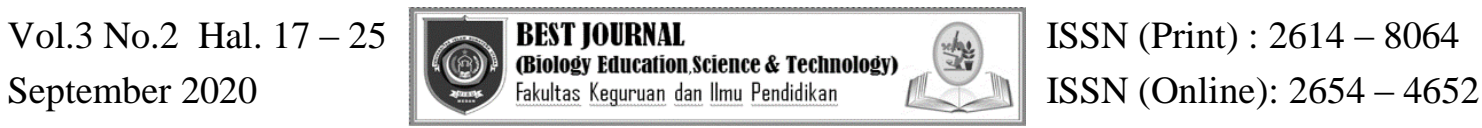

\title{
Pengaruh Faktor Iklim Terhadap Sintesis Amilosa (Sebuah Kajian Literatur)
}

\author{
Trisna Amelia \\ Program Studi Pendidikan Biologi, Fakultas Keguruan dan Ilmu Pendidikan, \\ Universitas Maritim Raja Ali Haji, Tanjungpinang \\ Trisna.amelia@umrah.ac.id
}

\begin{abstract}
ABSTRAK
Artikel ini ditulis untuk mendeskripsikan pengaruh faktor iklim terhadap sintesis amilosa yang dikaji melalui metode telaah kepustakaan. Amilosa bersama amilopektin merupakan dua polimer glukosa yang menyusun pati Amilosa merupakan bagian terpenting dari pati pada padi yang mempengaruhi kualitas nasi. Sifat tekstur beras yang dimasak dipengaruhi oleh perbandingan antara kadar amilosa dan amilopektinnya. Namun, kadar amilosa lebih dominan dalam menentukan sifat tekstur nasi. Fakta ini menjadikan amilosa sebagai indicator utama penentu kualitas nasi yang merupakan komoditas pangan pokok di Indonesia. Faktor iklim yang telah diketahui memperngaruhi proses sintesis amilosa adalah suhu (temperatur). Perubahan suhu lingkungan akan berpengaruh terhadap disintesisnya enzim GBSS1 yang mengkatalis sintesis amilosa. Diketahui bahwa enzim GBSS1 dikode oleh 2 alel yaitu Wxa dan Wxb. Alel Wxb merupakan alel yang sensitif terhadap perubahan suhu, sedangkan alel Wxa tidak terpengaruh oleh suhu rendah ataupun tinggi.
\end{abstract}

Kata Kunci : Faktor iklim, sintesis amilosa, kualitas nasi, perubahan suhu, enzim GBSS1

\begin{abstract}
This article was written to describe the effect of climatic factors on amylose synthesis which was examined through a literature review method. Amylose with amylopectin are two glucose polymers that make up Amylose starch. This is the most important part of starch in rice which affects the quality of rice. The texture of cooked rice is influenced by the ratio between the level of amylose and amylopectin. However, amylose content is more dominant in determining the nature of rice texture. This fact makes amylose as the main indicator of determining the quality of rice which is a staple food commodity in Indonesia. The climate factor that has been known to influence the amylose synthesis process is temperature. Changes in environmental temperature will affect the synthesis of the enzyme GBSS1 which catalyzes the synthesis of amylose. It is known that the GBSS1 enzyme is encoded by 2 alleles, namely Wxa and Wxb. Wxb alleles are alleles that are sensitive to temperature changes, whereas Wxa alleles are not affected by low or high temperatures.
\end{abstract}

Keywords : Climate factors; amylose synthesis; rice quality; temperature changes; the enzyme GBSS1 


\section{PENDAHULUAN}

\section{Latar Belakang}

Beras merupakan komoditas pertanian yang menjadi sumber karbohidrat utama bagi banyak negara di berbagai belahan dunia termasuk Indonesia. Karbohidrat sebagai penyusun utama beras memiliki pati sebagai komponen utama dari polimer glukosa pada beras. Sekitar 80$85 \%$ komponen beras dari padi adalah pati. Pati disusun oleh 2 polimer glukosa utama, yaitu amilosa dan amilopektin (Hanashiro, dkk., 2008). Kedua polimer ini berbeda dalam hal struktur dan ukuran (Denyer, dkk., 2000). Pada berbagai daerah di Indonesia terdapat ragam varitas beras yang beberapa di antaranya dinamai sesuai dengan daerahnya, misalnya beras solok, beras cianjur, dan beras banyuwangi. Berdasarkan varietasnya dikenal beras rojolele, beras bulu, beras IR, serta beras cisadane. Penggolongan beras berdasarkan varietasnya, dapat diketahui bedanya terutama dari tekstur nasi yang dihasilkan. Sifat tekstur beras yang dimasak dipengaruhi oleh perbandingan antara kadar amilosa dan amilopektinnya. Namun, kadar amilosa lebih dominan dalam menentukan sifat tekstur nasi (Aliawati, 2003). Telah dikatahui bahwa beras dengan kadar amilosa rendah (10-20\%) bila dimasak menghasilkan nasil yang lengket, mengilap, tidak mengembang dan tetap menggumpal setelah dingin. Contoh beras ini adalah beras varietas cisadane. Beras dengan kadar amilosa sedang (20$25 \%$ ) bila dimasak menghasilkan nasi yang sedang, merupakan jenis nasi yang banyak digemari orang Indonesia. Beras dengan kandungan amilosa sedang contohnya beras IR 64 dengan kandungan amilosa 24\%. Di sisi lain, beras dengan kadar amilosa tinggi (25-32\%) bila dimasak menghasilkan nasi yang tidak lengket, tidak mengembang dan menjadi keras jikas sudah dingin. Contohnya beras vaietas IR 36 dengan kadar amilosa 25\% (Nopianto, Tanpa Tahun). Walaupun telah diketahui faktor yang menyebabkan berbedanya tekstur nasi yang dihasilkan dari beras yang beragam, tetap tidak bisa dilepaskan asumsi bahwa kepulenan dan tekstur nasi merupakan ciri khas dari daerah masing-masing. Berbicara mengenai daerah penghasil, tentu tidak terlepas dari berbagai faktor fisik dan kimiawi lingkungan pada daerah tersebut sehingga menghasilkan beras dengan kualitas beragam. Iklim merupakan faktor yang secara umum berbeda pada setiap daerah. Perbedaan kondisi iklim tentu saja memberikan pengaruh terhadap komoditas pertanian yang tumbuh, termasuk padi. Untuk mengkaji pengaruh faktor iklim terhadap perbedaan kualitas padi terutama diukur dari kandungan amilosa yang mempengaruhi tekstur nasi, maka penulis melakukan kajian pustaka yang dirangkum dalam artikel ini.

\section{Perumusan Masalah}

Dalam studi kepustakaan ini terdapat dua (2) rumusan masalah yang akan dijawab, yaitu: (1) bagaimana peranan amilosa sebagai salah satu tolok ukur kualitas padi/nasi?, dan (2) bagaimana pengaruh factor iklim terhadap kandungan amilosa padi?

\section{Tujuan Penelitian}

Studi kepustakaan ini bertujuan untuk mendeskripsikan peranan kandungan amilosa sebagai salah tolok ukur untuk mengetahui kualitas padi/ nasi dan untuk mendeskripsikan pengaruh faktor iklim terhadap kandungan amilosa amilosa pada padi.

\section{Manfaat Penelitian}

Kajian ini akan memberikan manfaat kepada masyarakat akademis sebagai sumber informasi mengenai kandungan amilosa pada padi serta pengaruhnya terhadap tekstur nasi yang merupakan makanan pokok masyarakat Indonesia. Selanjutnya, telaah ini diharapkan memberikan informasi mengenai pengaruh faktor iklim terhadap kandungan amilosa padi. Secara lebih luas kajian ini diharapkan bermanfaat untuk menunjang pengetahuan akademisi 
dan peneliti dalam mengkaji serta melakukan penelitian terhadap berbagai varietas padi, juga tidak menutup kemungkinan menjadi dasar dalam mengambil langkah peningkatan atau memodifikasi kualitas padi.

\section{METODE PENELITIAN}

Studi ini dilakukan dengan metode telaah kepustakaan, di mana yang menjadi sumber data adalah laporan hasil penelitian tertulis baik data primer maupun sekunder. Data hasil penelitian yang sudah dilakukan oleh peneliti terdahulu menjadi sumbangan besar dalam membangun kerangka penulisan ini. Data yang diperoleh berupa data deskriptif, yang dikumpulkan dari berbagai buku (cetak dan elektronik) dan artikel ilmiah. Data deskriptif ini kemudian ditelaah/ dianalisis dan direduksi sesuai dengan kerangka penulisan.

\section{HASIL DAN PEMBAHASAN}

\section{Amilosa sebagai Salah Satu Komponen Penyusun Pati}

Pati sebagai polisakarida simpanan pada tumbuhan merupakan polimer yang secara keseluruhan terdiri dari monomer-monomer glukosa. Tumbuhan menumpuk pati di dalam granula atau butiran di dalam struktur seluler yang disebut plastid (Campbell, dkk., 2000). Tumbuhan menyimpan kelebihan gula dengan cara mensintesis pati. Bagi tumbuhan, pati berfungsi sebagai cadangan makanan, sementara bagi manusia pati pada tumbuhan merupakan sumber karbohidrat dalam pangan.

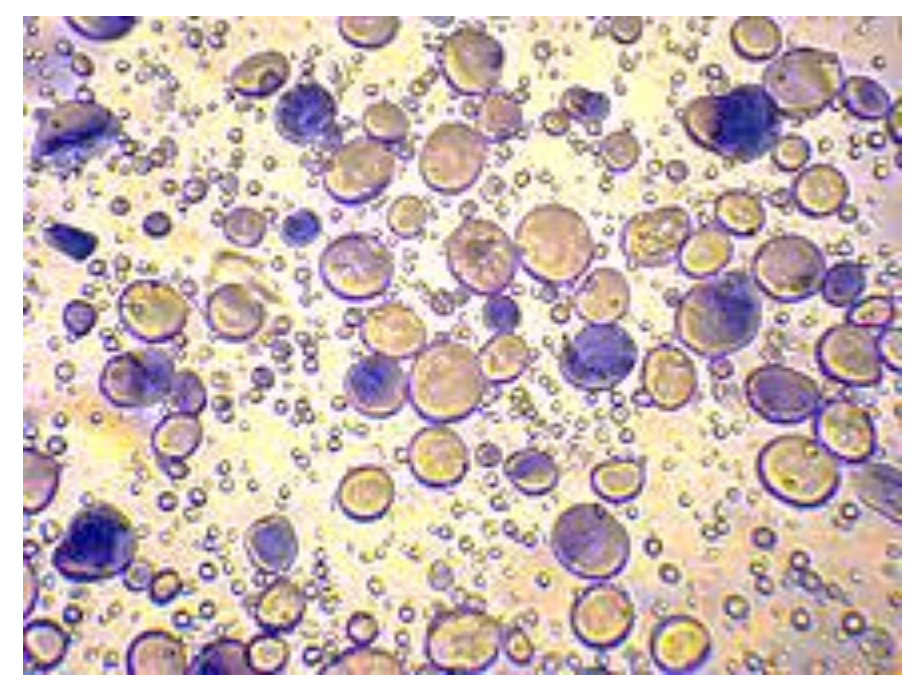

Gambar 1. Granula Padi Setelah Dilakukan Pewarnaan dengan Iodin (American Heritage Dictionary, 2012)

Dijelaskan oleh David dan Michael (2008) bahwa amilosa bersama dengan amilopektin merupakan dua polimer glukosa yang menyusun pati. Segmen amilosa merupakan polimer ikatan D-glukosa linear yang berikatan pada ikatan $\alpha$ 1-4 glikosidik dan pada setiap rantai amilosa bisa terdapat 500-2000 unit D-glukosa. 


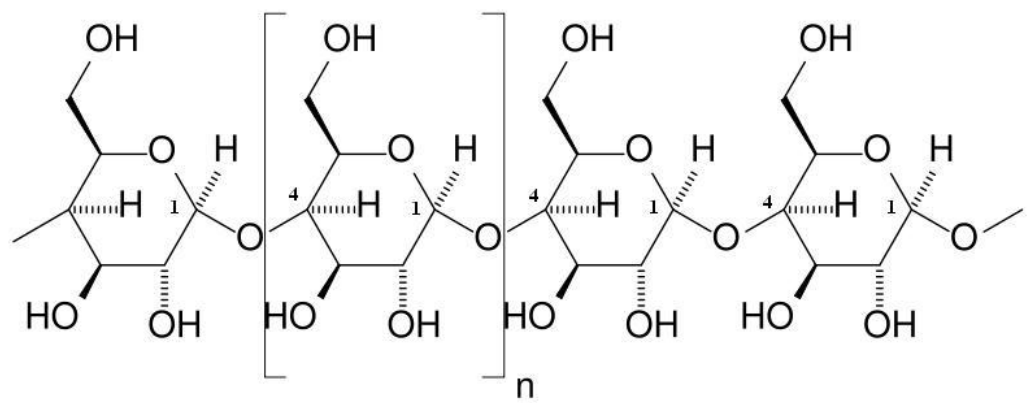

Gambar 2. Struktur Molekul Amilosa sebagai Polimer Glukosa (Wikipedia, 2012)

Menurut Campbell, dkk. (2000), sudut ikatan glikosidik seperti pada amilosa menyebabkan polimer tersebut berbentuk helix. Amilosa dengan rantai berbentuk heliks tidak memiliki percabangan dalam struktur molekulnya. Struktur amilosa yang seperti ini menyebabkannya bersifat hidrofobik dan memungkinkan terjadinya kristalisasi jika berada di dalam larutan. Amilosa tidak larut dalam air dingin, namun dapat larut dalam air panas dengan suhu $600 \mathrm{C}$ -800C. Denyer (2000) menjelaskan bahwa selama berada di dalam organ penyimpanan, jumlah amilosa biasanya akan meningkat sesuai dengan umur tanaman. Contohnya, pada maizena peningkatan jumlah amilosa dapat terjadi dari $18 \%$ menjadi $26,5 \%$ pada hari ke 14 sampai hari ke 28 setelah polinasi. Tumbuhan serealia dewasa pada umumnya dapat mengandung rata-rata 25\%-30\% kandungan amilosa. Amilosa merupakan bagian terpenting dari pati pada padi yang mempengaruhi kualitas nasi. Analisis terhadap struktur amilosa melibatkan analisis terhadap molekul penyusun amilosa.

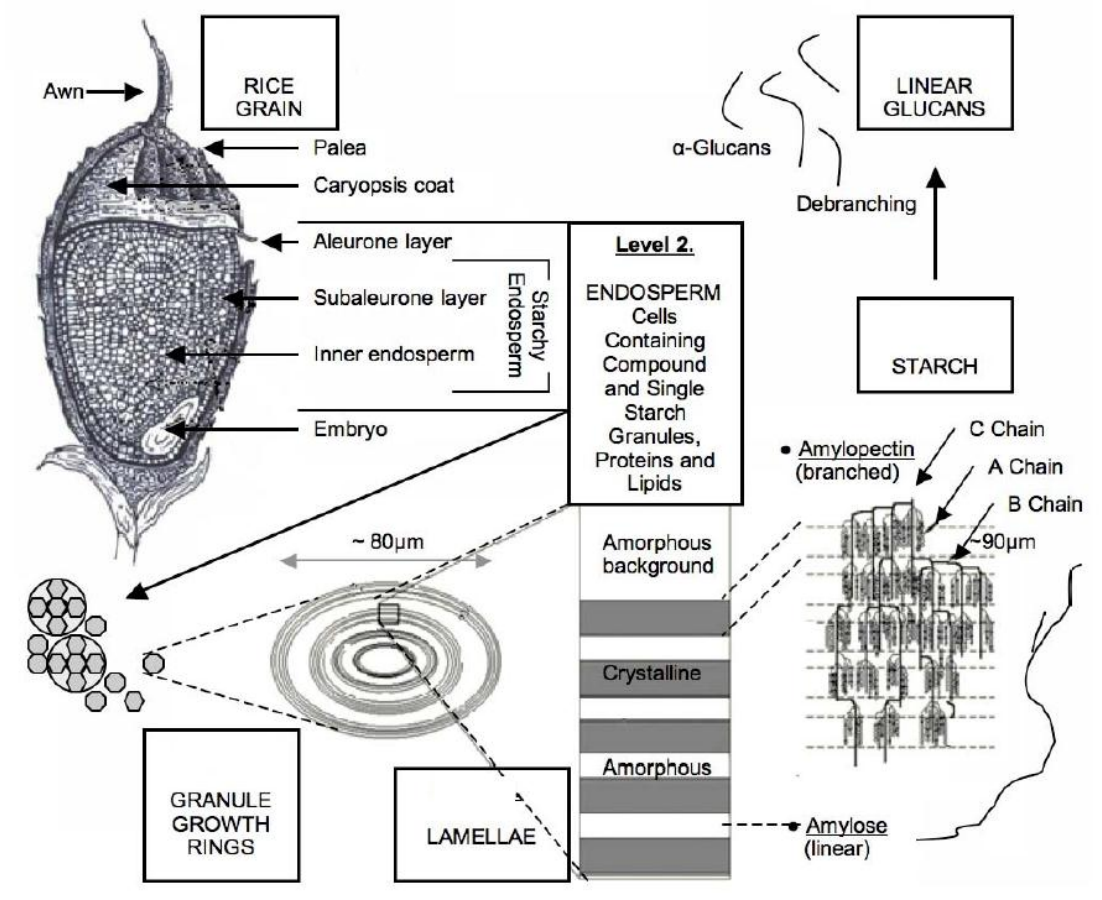

Gambar 3. Amilosa sebagai Bagian dari Pati pada Padi (Ward, 2007)

\section{Sintesis Amilosa}

Sintesis amilosa berlangsung di dalam amiloplas (Kuipers, dkk., 1994),. Proses sintesis dikatalis oleh granule-bound starch synthase (GBSS). Dijelaskan oleh Hanashiro, dkk. (2008) bahwa GBSS ini biasanya ditemukan sebagai rantai isozim yang terdapat di dalam granula pati. Berdasarkan penelitian yang dilakukan Kuipers dkk., dengan menganalisis 
produksi pati dan komposisi granula pati pada umbi kentang transgenik, diketahui bahwa pengurangan aktivitas GBSS berpengaruh terhadap pengurangan produksi amilosa. Sejalan dengan pendapat tersebut, Ward (2007) juga menjelaskan bahwa amilosa disintesis melalui reaksi yang dikatalis oleh enzim Granule Bound Starch Synthase 1 (GBSS1). Enzim ini mengkatalis reaksi penambahan molekul glukosa 1-pospat kepada rantai glukosa melalui ikatan $\alpha-(1-4)$ glikosidik. Produk akhir dari reaksi ini berupa molekul amilosa dengan massa jenis molekul sekitar 1110. Menurut Ward (2007), persentase efektivitas sintesis amilosa dipengaruhi oleh keberadaan adenosin dipospat-glukosa (ADP-glukosa), aktivitas transpor protein oleh ADP/ATP, kecukupan ruang pada granula, dan kapasitas enzim GBSS1. Pembentukan enzim GBSS1 dikode oleh gen Wx. Kode Wx untuk gen ini mengacu kepada istilah keperaan atau tekstur keras pada beras (waxy, disingkat wx) (Hanashiro, dkk., 2008). Mengenai gen ini, lebih lanjut Ward (2007) menjelaskan bahwa pada lokus gen pencetak enzim GBSS1 ini terdapat dua alel fungsional yaitu Wxa dan Wxb. Pada tumbuhan dengan kadar amilosa sedang dan tinggi, terdapat alel Wxa yang memproduksi lebih banyak protein GBSS1 dan amilosa, sedangkan pada varietas tumbuhan dengan kadar amilosa rendah terdapat alel Wxb yang mengkode produksi protein GBSS1 dan amilosa yang lebih sedikit. Kedua alel ini terdapat pada padi varietas indica, sementara itu pada padi varietas japonica hanya alel Wxb yang telah ditemukan. Berdasarkan keberadaan kedua alel ini pada gen pengkode GBSS1, muncul istilah waxy dan non waxy untuk menyatakan tekstur keperaan pada beras sebagai pengaruh dari kandungan amilosanya. Penelitian yang dilakukan oleh Takeda (1987), dijelaskan oleh Hanashiro, dkk. (2008) bahwa varietas padi indica mengandung amilosa dengan kadar lebih tinggi dari pada padi varietas japonica. Tingginya kadar amilosa pada varietas indica disebabkan oleh adanya extra long chains (ELC) dari amilopektin yang tidak ditemukan pada varietas japonica. Dengan demikiam, dari penelitian ini juga disimpulkan bahwa keberadaan rantai bercabang yang panjang (ELC) pada amilopektin juga berkorelasi positif dengan jumlah amilosa yang terkandung di dalam pati.

\section{Pengaruh Faktor Iklim terhadap Sintesis Amilosa}

Secara alami, keberagaman kondisi iklim mempengaruhi kualitas bulir padi yang dihasilkan dari budidaya sehingga lingkungan iklim tertentu dapat dikatakan sesuai untuk pertumbuhan varietas padi tertentu. Secara umum, padi yang tumbuhan di berbagai belahan dunia pada umumnya adalah dari golongan varietas non-waxy atau tidak pera. Dengan demikian, dapat dikatakan bahwa kebanyakan padi di seluruh dunia mengandung protein fungsional berupa enzim GBSS1 yang mengkatalis sintesis amilosa. Kandungan amilosa dalam bulir padi telah dijadikan sebagai ukuran kualitas padi, sehingga pengertian akan bagaimana pengaruh iklim terhadap kualitas padi akan merujuk kepada bagaimana pengaruh iklim terhadap kandungan amilosa. Berdasarkan berbagai penelitian yang telah dilakukan, tidak semua faktor iklim mempengaruhi sintesis amilosa. Telah dilaporkan bahwa faktor iklim yang mempengaruhi sintesis amilosa adalah faktor suhu. Menurut Ward (2007), ketika padi terpapar terhadap temperatur tinggi pada saat perbungaan dan pematangan, respon fenotip yang terjadi pada sebagian besar varietas adalah terjadinya peningkatan kadar amilosa. Mengenai bagaimana suhu lingkungan berpengaruh terhadap kadar amilosa tanaman (khususnya padi), dari penelitian Haryanto (2008) telah membuktikan bahwa varietas padi yang sama dapat mengandung kadar amilosa yang berbeda apabila ditanam pada lingkungan yang berbeda. Dalam penelitian tersebut, 11 varietas padi yang berbeda genotipnya, ditanam pada daerah yang berbeda yaitu Banyumas dan Sleman. Penelitian ini memperoleh hasil sebagai berikut. 
Tabel 1. Perbandingan Kandungan Amilosa Beberapa Varietas Padi yang Ditanam di Banyumas dan Sleman

\begin{tabular}{|l|c|c|c|c|}
\hline \multirow{2}{*}{ Genotip } & \multicolumn{2}{|c|}{ Banyumas } & \multicolumn{2}{c|}{ Sleman } \\
\cline { 2 - 5 } & Amilosa (\%) & Kriteria & Amilosa (\%) & Kriteria \\
\hline G9 & 27,84 & Tinggi & 14,65 & Rendah \\
\hline G10 & 26,70 & Tinggi & 14,81 & Rendah \\
\hline G12 & 26,77 & Tinggi & 19,25 & Rendah \\
\hline G13 & 24,41 & Sedang & 16,41 & Rendah \\
\hline G34 & 28,62 & Tinggi & 15,10 & Rendah \\
\hline G35 & 21,77 & Sedang & 14,18 & Rendah \\
\hline G39 & 28,05 & Tinggi & 14,28 & Rendah \\
\hline G136 & 23,70 & Sedang & 20,64 & Sedang \\
\hline Mentik Wangi & 27,27 & Tinggi & 19,97 & Rendah \\
\hline Situpatenggang & 26,91 & Tinggi & 14,86 & Rendah \\
\hline
\end{tabular}

Sumber: Haryanto, 2008

Dari Tabel 1 dikatahui terdapat perbedaan kadar amilosa yang signifikan pada 11 varietas yang ditanam di Banyumas dan Sleman. Berdasarkan data, dua daerah ini merupakan daerah dengan suhu rata-rata yang berbeda. Banyumas memiliku suhu rata-rata 26,30C, sementara Sleman memiliki suhu rata-rata 320C (Dinas Kependudukan dan Pencatatan Sipil Kota Banyumas, 2010 dan Wikipedia, 2011). Perbedaan suhu inilah yang diperkirakan menyebabkan perbedaan kadar amilosa pada varietas padi yang sama jika ditanam di Banyumas dan Sleman. Hal ini sesuai dengan penjelasan sebelumnya bahwa peningkatan suhu pada batas tertentu akan menurunkan kadar amilosa tanaman (padi). Kondisi suhu selama masa pertumbuhan tanaman memang telah diketahui mempengaruhi sintesis amilosa. Pada temperatur relatif rendah (dingin), jumlah protein yang mengekspresikan alel Wxb lebih tinggi, sehingga produksi amilosa juga tinggi. Pada temparatur tinggi, terjadi mutasi pada alel Wxb. Kondisi ini menyebabkan alel Wxb tidak dapat diterjemahkan sehingga mengurangi jumlah amilosa yang disintesis. Berbeda dengan alel Wxb, alel Wxa tidak sensitif terhadap suhu rendah dan tidak terganggu oleh suhu tinggi. Secara umum korelasi antara keberadaan gen Wx dengan kandungan amilosa digambarkan oleh Itoh, dkk. (2003) dari hasil penelitiannya sebagai berikut.

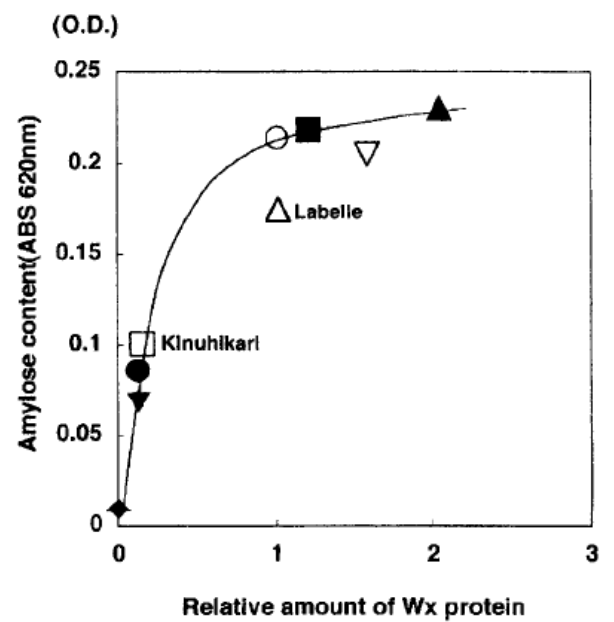

Gambar 4. Hubungan kandungan amilosa dengan jumlah gen Wx (Sumber: Itoh, dkk (2003)) 
Penelitian yang dilakukan oleh Huawa Jiang dkk. dalam Jiang dkk. (2003) terhadap aktivitas enzim yang berperan dalam biosintesis amilosa dan amilopektin menunjukkan hasil bahwa aktivitas enzim GBSS1 memang dipengaruhi oleh faktor suhu. Menurut penelitian ini, pada dua rentang suhu yang berbeda enzim GBSS1 menunjukkan aktivitas yang berbeda pula. Pada suhu antara 290 C-350 C aktivitas enzim GBSS1 relatif lebih rendah. Sebaliknya pada suhu antara $220 \mathrm{C}-280 \mathrm{C}$ aktivitas enzim ini relatif lebih tinggi.Selain faktor suhu, faktor kadar $\mathrm{CO} 2$ juga telah diteliti terkait dengan pengaruh iklim terhadap sintesis amilosa. Namun, melalui penelitian yang dilakukan oleh Ward, dkk. diketahui bahwa kadar CO2 tidak memperngaruhi sintesis amilosa. Penelitian Ward dkk. dilakukan dengan menggunakan 3 varietas padi dari 3 negara yang berbeda (varietas Amaroo dari Australia dengan kadar amilosa alami 19\%, varietas IR 64 dari Filipina dengan kadar amilosa alami 24\%, dan varietas Taipei 309 dari Taiwan dengan kadar amilosa alami 17\%). Dengan mengkondisikan sampel padi pada 4 perlakuan dengan suhu dan kadar $\mathrm{CO} 2$ berbeda diperoleh hasil sebagai berikut.

Tabel 2. Perbandingan Kadar Amilosa pada Perlakuan Suhu dan Kadar $\mathrm{CO}_{2}$ terhadap Beberapa Varietas padi

\begin{tabular}{|l|l|l|l|l|l|}
\hline Perlakuan & Temperatur & $25 / 19^{0} \mathrm{C}$ & $25 / 19^{0} \mathrm{C}$ & $30 / 20^{0} \mathrm{C}$ & $30 / 20^{0} \mathrm{C}$ \\
\cline { 2 - 6 } & $\mathrm{CO}_{2}$ & $380 \mathrm{ppm}$ & $780 \mathrm{ppm}$ & $380 \mathrm{ppm}$ & $780 \mathrm{ppm}$ \\
\hline Parameter & Varietas & \multicolumn{4}{|l|}{} \\
\hline $\begin{array}{l}\text { Kandungan } \\
\text { Amilosa }\end{array}$ & Amaroo & $16,6 \pm 0,3$ & $17,1 \pm 0,4$ & $15,4 \pm 0,3$ & $14,0 \pm 0,2$ \\
\cline { 2 - 6 } & IR 64 & $24,7 \pm 0,2$ & $24,1 \pm 0,6$ & $21,3 \pm 0,2$ & $22,5 \pm 0,2$ \\
\cline { 2 - 6 } & Taipei 309 & $16,1 \pm 0,4$ & $16,9 \pm 0,2$ & $16,7 \pm 0,5$ & $16,7 \pm 0,3$ \\
\hline
\end{tabular}

Sumber: Ward, 2007

Dari Tabel 2, disimpulkan bahwa penurunan suhu dari suhu normal pertumbuhan padi pada ketiga varietas padi yang berbeda akan meningkatkan kandungan amilosa. Sebaliknya peningkatan suhu di atas suhu normal pertumbuhan menyebabkan penurunan kandungan amilosa padi. Di samping itu, perlakukan yang dilakukan dengan kadar CO2 yang berbeda, tidak memberikan pengaruh terhadap kandungan amilosa padi. Dari penelitian ini juga dijelaskan bahwa peningkatan kadar $\mathrm{CO} 2$ selama fase pertumbuhan padi berpengaruh terhadap pengurangan kandungan protein tanaman, namun tidak berpengaruh terhadap kandungan amilosa.

Selanjutnya, dalam penelitian ini juga dijelaskan hubungan kandungan amilosa dengan keberadaan enzim GBSS1 sebagai katalisator sintesis amilosa. Sebagai penjelasan yang memperlihatkan adanya korelasi positif kandungan amilosa dengan keberadan enzim GBSS1, Wadr dkk. melakukan pengujian menggunakan PCR terhadap gen yang mengkode GBSS1.

A

B C

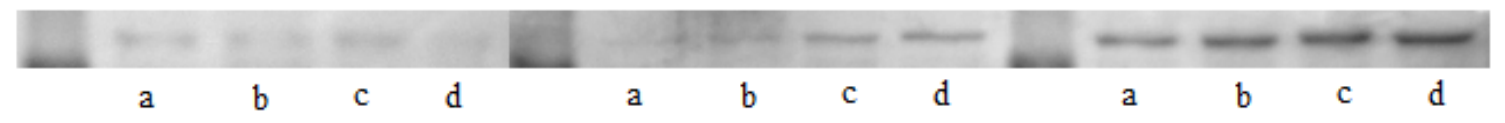

Keterangan: A: varietas Taipei 309

B: varietas Amaroo

C: varietas IR 64

a dan b: perlakuan dengan suhu lebih tinggi 
c dan d: perlakuan dengan suhu lebih rendah

Gambar 5. Hasil Analisis PCR terhadap Kandungan Gen Pengkode Enzim GBSS1 (Ward, dkk., 2007) Analisis PCR yang dilakukan oleh Ward, dkk. menjelaskan bahwa terdapat korelasi positif antara peningkatan kandungan enzim GBSS1 dengan kandungan amilosa. Dengan demikian jelas bahwa suhu sebagai faktor iklim memberikan pengaruh pada sintesis amilosa dengan mempengaruhi sintesis enzim GBSS1 sebagai katalisator. Kesimpulan ini sesuai dengan pendapat Nihayati, dkk. (1986) bahwa temperatur memperngaruhi kecepatan reaksi biokimia pada tumbuhan. Penurunan kecepatan reaksi pada suhu yang relatif tinggi disebabkan karena inactivering dari mekanisme reaksi (enzim menjadi tidak aktif).

\section{KESIMPULAN}

Terdapat beberapa hal yang dapat disimpulkan dari penulisan artikel ini, di ataranya sebagai berikut:

1. Amilosa dengan struktur linearnya merupakan polimer glukosa yang tersimpan di dalam granula pada tumbuhan serealia umumnya sebagai bentuk simpanan glukosa.

2. Amilosa merupakan salah satu komponen utama penyusun pati yang bersama-sama amilopektin mempengaruhi kualitas nasi yang dihasilkan dari padi.

3. Amilosa pada padi memiliki beberapa tingkatan dalam kandungannya, kandungan amilosa tersebut mempengaruhi keperaan nasi yang dihasilkan.

4. Faktor iklim yang telah diketahui memperngaruhi proses sintesis amilosa adalah suhu (temparetur). Perubahan suhu lingkungan akan berpengaruh terhadap disintesisnya enzim GBSS 1 yang mengkatalis sintesis amilosa.

5. Enzim GBSS1 dikode oleh 2 alel yaitu Wxa dan Wxb. Telah diketahui bahwa alel Wxb merupakan alel yang sensitif terhadap perubahan suhu, sedangkan alel Wxa tidak terpengaruh oleh suhu rendah ataupun tinggi.

\section{DAFTAR PUSTAKA}

Aliawati, Gusnimar. 2003. Teknik Analisis Kadar Amilosa dalam Beras. Buletin Teknik Pertanian (8: 2). Online, (http://203.190.37.42/publikasi/bt082031.pdf, diakses 5 Februari 2020)

American Heritage Dictionary. 2020. Starch. Online, (https://ahdictionary.com/word/search.html?q=starch, diakses 5 Februari 2020)

Campbell, Reece dan Mitchell. 2000. Biologi (Ed. 5). Jakarta: Erlangga.

Denyer, Kay. Philip Jhonson, Samuel Zeeman, dan Alison Smith. 2000. The Control of Amylose Synthesis. Journal of Plant Physiology (Vol 158: 479-487) . Online, (https://www.sciencedirect.com/science/article/pii/S0176161704700590, diakses 3 Februari 2020)

Dinas Kependudukan dan Pencatatan Sipil Kota Banyumas. 2010. Kondisi Wilayah Banyumas. Online, (http://dindukcapil-banyumas.blogspot.com, diakses 7 Februari 2020)

Hanashiro, Isao. Kimiko Itoh, Yuki Kuratomi, Mina Yanazaki, Toshinari Igarasi, Yun-ichi Matsugasako, dan Yasuhito Takeda. 2008. Granule-Bound Starch Synthase I is Responsible for Biosynthesis of Extra-Long Unit Chain of Amylopectin in Rice. Journal Plant Cell Physol (49: 925-933). Online, (https://pubmed.ncbi.nlm.nih.gov/18430767/, diakes pada 3 Februari 2020) 
Haryanto, Totok Agung Dwi. 2008. Mutiara yang Terlupakan: Upaya Peningkatan Ketahanan Pangan melalui Pengembangan Padi Gogo Aromatik. Orasi Ilmiah Guru Besar. Online, (http://pascaunsoed.files.wordpress.com, diakses 7 Februari 2020)

Jiang, Huawu, Weimin Dian, dan Ping Wu. (2003). Effect of High Temperature on Fine Structure of Amylopectin in Rice Endosperm by Reducing the Activity of the Starch Branching Enzyme. Abstract. Phytochemistry (Vol. 63: 1). Online, (https://pubmed.ncbi.nlm.nih.gov/12657298/, diakses pada 3 Februari 2020)

Kuipers, Jacobsen dan Vissser. 1994. Formation and Deposition of Amylose in Potato Tuber Starch Granule Are Affected by the Reduction of Granule-Bound Starch Synthase Gene Expression. Abstract. The Plant Cell (Vol. 6: 1). Online, ( http://www.plantcell.org/content/plantcell/6/1/43.full.pdf diakses pada 3 Februari 2020)

Nelson, David, dan Michael M. Cox. 2008. Principles of Biochemistry. England: W.H Freeman and Company.

Nihayati, dkk. 1986. Biologi Pertanian: Tinjauan Singkat tentang Anatomi, Fisiologi, Sistematika, dan Genetika Dasar Tumbuh-Tumbuhan. Jakarta: Rajawali Press.

Nopianto, Eko. Tanpa Tahun. Komoditas Sumber Karbohidrat. Online, (https://www.scribd.com/document/34046429/2-Protein, diakses pada 2 Februari 2020)

Ward, Rachele Maree. 2007. Potential Impact of Temperature and Carbondioxide Level s on Rice Quality. Thesis in School of Chemistry, The University of Sidney. Online, (https://core.ac.uk/download/pdf/41231007.pdf pada 2 Februari 2020)

\begin{tabular}{|l|l|l|l|}
\hline Accepted Date & Revised Date & Decided Date & Accepted to Publish \\
\hline 04 Juli 2020 & 06 Juli 2020 & 12 Agustus 2020 & Ya \\
\hline
\end{tabular}

